\title{
En glemt pioner
}

\author{
Antallet meslingtilfeller i Europa har økt betydelig de siste fem årene, og fra hele verden rapporteres det om \\ meslingepidemier. Det er et tragisk paradoks at meslingvaksinen synes å ha blitt offer for sin egen suksess \\ og at mannen som sto bak forskningen som ga oss MMR-vaksinen nesten er glemt.
}

\section{Jakob Klcovansky \\ jakklc@ous-hf.no}

Meslinger er en av de mest smittsomme sykdommene som finnes og er svært vanlig i land med lav vaksinasjonsdekning. Spesielt hos spedbarn kan sykdomsforløpet være alvorlig, og omkring én av tusen personer med meslinger får alvorlige komplikasjoner, for eksempel encefalitt (1). En av de viktigste årsakene til den økende forekomsten av meslinger i den vestlige verden er at vaksinasjonsraten i mange land har sunket til under $95 \%$, noe som anses som grensen for å få flokkimmunitet i en befolkning (2). Vaksinemotstandere i den vestlige verden er ofte godt utdannet og økonomisk velstående. De lar som regel være å vaksinere barna sine fordi de tror vaksinen kan ha alvorlige bivirkninger. I 1950-årene var det ingen husmødre eller allmennleger som ikke umiddelbart gjenkjente en person med meslinger. $\mathrm{Da}$ meslingvaksinen ble innført i 1960-årene, var det et kraftig fall i forekomsten av sykdommen, og mot slutten av det siste århundret var den blitt sjelden. For 15 år siden fantes sykdommen nesten ikke i USA, men den har dessverre fătt et oppsving siden da.

\section{Meslingutbrudd}

Vinteren 2015 ble det bekreftet totalt 125 tilfeller av meslinger knyttet til et utbrudd av meslinger i Los Angeles. Mer enn 40\% av de smittede var ikke vaksinert (3). De siste årene har det også i flere europeiske land vært stor motstand mot vaksinering, spesielt i Frankrike der man hadde over 20000 tilfeller av meslinger i 2008-2011 (4). I 2001-10 lå antallet meslingtilfeller i USA på rundt 60 per år, men i 2014 ble det rapportert nesten 650 tilfeller av meslinger i landet (5). Dette står i sterk kontrast til 2000, da Center for Disease Control and Prevention (CDC) erklærte at man ikke lenger hadde meslinger i USA (5).

\section{Vaksineparadokset}

Siden 1990-årene er vaksinering av barn blitt kontroversielt i mange deler av den vestlige verden (6). I takt med at insidensen av tidligere dødelige sykdommer har falt kraftig, har det vokst opp flere generasjoner som ikke har sett disse sykdommenes naturlige forløp og ofte alvorlige komplikasjoner. Man kan med god grunn hevde at vaksiner er en medvirkende faktor til at familier i den vestlige verden nå bare skaffer seg 2-3 barn, da man som forelder kan være rimelig sikker på at barna vil overleve til voksen alder (6). Vaksiner generelt - og meslingvaksinen spesielt - er blitt offer for sin egen suksess ved at de indirekte har vært med på å skape grobunn for dagens vaksineskepsis. For de fleste i helsevesenet skaper dette problemer og er for mange av oss vanskelig å forstå. Én mann ville sørget mer over dette fenomenet enn andre: Maurice Hilleman. Han var sannsynligvis den største vitenskapsmannen du aldri har hørt om - rett og slett en glemt pioner. I år er det ti år siden han døde.

\section{Maurice Hilleman}

Maurice Ralph Hilleman ble født 20. august $1919 \mathrm{i}$ en liten by i Montana og gikk bort 11. april 2005. Han var den yngste av åtte barn (7). Tvillingsøsteren døde under fødselen, og moren døde i barselkomplikasjoner bare et par dager senere. Familiens dårlige økonomi vanskeliggjorde høyere utdanning, men med finansiell hjelp fra en eldre bror fikk han begynne å studere. I 1941 disputerte Hilleman i mikrobiologi og fikk kort tid etter en jobb i legemiddelindustrien. Her utviklet han blant annet en vaksine mot japansk B-encefalitt, en sykdom som rammet mange amerikanske soldater som var stasjonert i Stillehavet under den annen verdenskrig (7). I 1948 ble Hilleman sjef for lungeavdelingen ved Army Medical Center i Washington DC. I 1957 forte hans banebrytende forskning til en masseproduksjon av 40 millioner doser av influensavaksine for å beskytte mot den fryktede Hong Kong-influensaen $(7,8)$.

En natt i mars 1963 ble tobarnsfaren Hilleman vekket av sin fem år gamle datter fordi hun hadde feber, hoven kjeve og sår hals. Hun hadde fått kusma (parotitis epidemica). Hilleman la henne til sengs igjen og kjørte rett til sitt laboratorium der han hentet det nødvendige utstyret for prøvetaking. Da han kom tilbake til huset, vekket han sin datter og tok raskt en prøve fra halsen hennes før han la henne til å sove igjen. Det var starten på forskningen som til slutt førte til den kombinerte MMR-vaksinen i 1971 (Measles-Mumps-Rubella; kusma-meslinger-røde hunder). Tidligere hadde barn blitt vaksinert med totalt seks injeksjoner for disse sykdommene, men Hilleman og medarbeidere klarte å kombinere alle tre vaksiner i ett enkelt preparat som bare trengte å bli injisert to ganger. Den parotitisvirusstammen Hilleman isolerte fra sin datter, brukes fortsatt i den gjeldende versjonen av vaksinen.

Den første vaksinen mot meslinger kom på markedet i 1963, og i årene som fulgte falt forekomsten av meslinger i USA fra over 500000 tilfeller i året til ca. 50 000; en nedgang på over $90 \%$ (9). I løpet av de første 20 årene etter at meslingvaksinen ble satt i produksjon, har man anslått at vaksinen forhindret 52 millioner sykdomstilfeller og 5200 dødsfall (10). Da president Reagan i 1988 belønnet Hilleman med National Medal of Science - USAs høyeste vitenskapelige utmerkelse - ble det sagt at han hadde reddet flere liv enn noen annen vitenskapsmann på 1900-tallet (11).

I løpet av karrieren utviklet Hilleman mer enn 40 vaksiner, bl.a. mot meslinger, hepatitt A og B, meningokokker, pneumokokker og Haemophilus influenzae. Han var direkte ansvarlig for utviklingen av åtte av de 14 vaksinene som brukes i barnevaksinasjonsprogrammet i USA, og står bak fire av de foreløpig ti vaksinene i det norske barnevaksinasjonsprogrammet - et tall som vil øke til fem om hepatitt B-vaksine blir innført i Norge (12). Hillemans genialitet lå ikke bare i kombinasjonen av flere vaksiner i én vaksinasjon, men også i hans arbeid for å redusere vaksinenes bivirkninger $(7,8,11)$.

De fleste vaksiner er profylaktiske, dvs. at de blir administrert til friske individer for å unngå å bli rammet av sykdom. Hilleman var en av mange vaksinologer som tenkte på terapeutiske vaksiner. Disse skulle lindre symptomer og sykdomsutvikling hos mennesker som allerede var blitt smittet med sykdom, som for eksempel malaria, tuberkulose og hiv (13).

\section{MMR-vaksinen og autismefrykt}

Etter en artikkel publisert i The Lancet 1998 oppsto det en voldsom debattstorm rundt 


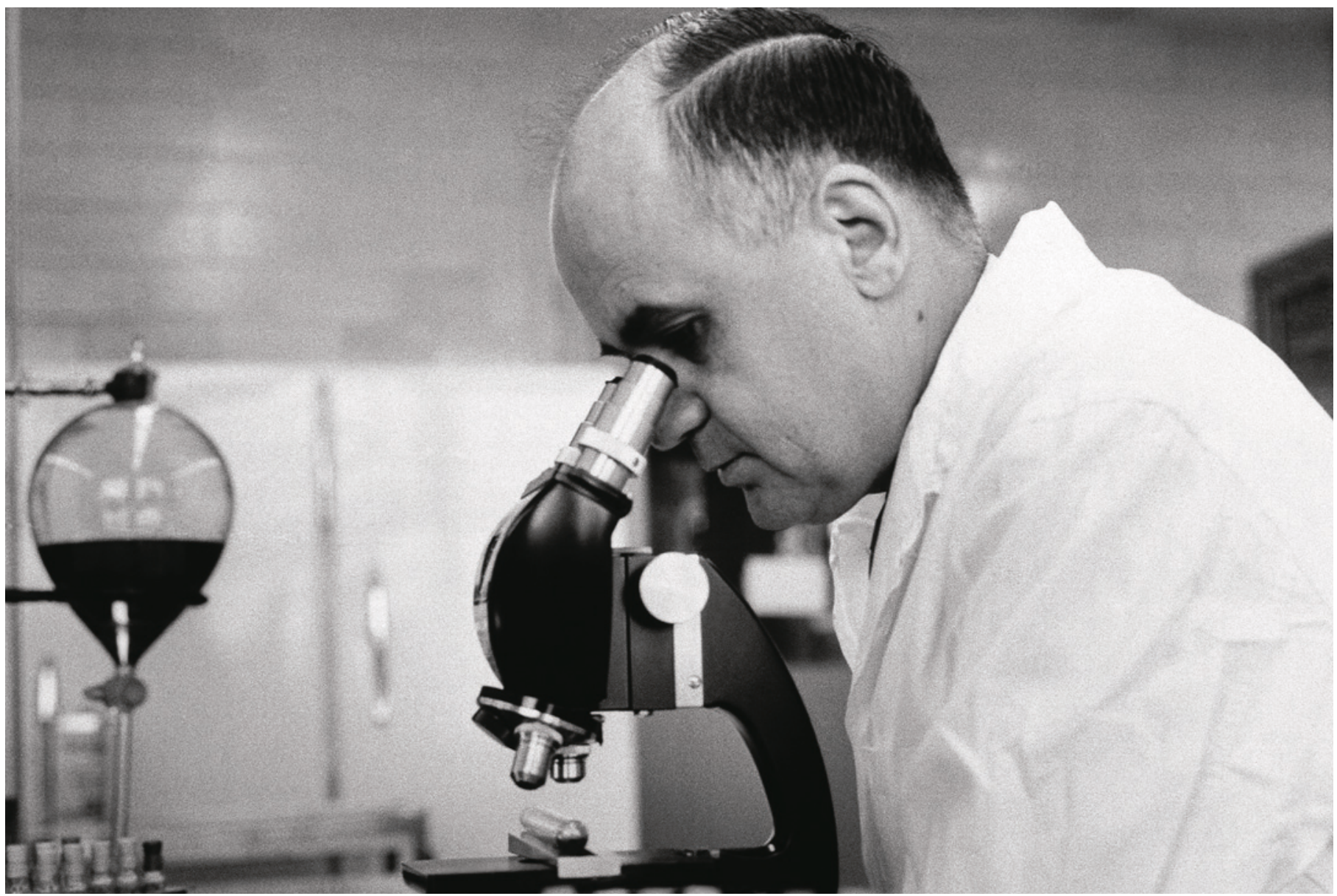

Maurice Hilleman. Foto: AP/NTB Scanpix

MMR-vaksinen (14). Basert på undersøkelser av 12 barn stilte man i studien, som ble ledet av gastroenterologen Andrew Wakefield, spørsmålet om det kunne være en sammenheng mellom MMR-vaksinen, autisme og tarmsykdom. General Medical Council i England konkluderte i 2010 med at Wakefield hadde handlet uetisk, blant annet ved å unnlate å oppgi hvordan pasientene ble rekruttert og egne potensielle finansielle interesser. The Lancet trakk da artikkelen tilbake.

I flere store epidemiologiske studier har man i ettertid konkludert med at det ikke finnes holdepunkter for noen sammenheng mellom MMR-vaksinen og utvikling av autisme hos barn $(14,15)$. Men skaden var allerede skjedd. De regelmessige meslingutbruddene $i$ hele den vestlige verden de siste årene, nå sist i USA, skyldes hovedsakelig vaksinemotstandere som nekter sine barn en effektiv beskyttelse mot en av verdens mest smittsomme og potensielt dødelige sykdommer. Maurice Hilleman gikk fra å ha vært en nobelpriskandidat til mot slutten av sitt liv å få hatbrev og trusler på grunn av påståtte bivirkninger av MMR-vaksinen. Robert Gallo, en av forskerne bak oppdagelsen av hiv, kommenterte utviklingen slik: «If I had to name a person who has done more for the benefit of human health, with less recognition than anyone else, it would be Maurice Hilleman. Maurice should be recognized as the most successful vaccinologist in history.» (16). Men Maurice Hilleman er dessverre blitt en glemt pioner. Og det er synd og skam.

\section{Jakob Klcovansky (f. 1980)}

er spesialist i barnesykdommer med fordypningsstilling i barnekardiologi ved Oslo universitetssykehus, Rikshospitalet.

Forfatter har fylt ut ICMJE-skjemaet og oppgir ingen interessekonflikter.

\section{Litteratur}

1. Gans H, Maldonado YA. Clinical manifestations and diagnosis of measles. UpToDate. www.uptodate.com/contents/clinicalmanifestations-and-diagnosis-of-measles (8.7.2015)

2. University of Oxford. The Vaccine Knowledge Project. www.ovg.ox.ac.uk/herd-immunity (7.5.2015).

3. Zipprich J, Winter K, Hacker J et al. Measles outbreak - California, December 2014-February 2015. MMWR Morb Mortal Wkly Rep 2015; 64 : 153-4.

4. Antona D, Lévy-Bruhl D, Baudon C et al. Measles elimination efforts and 2008-2011 outbreak. France. Emerg Infect Dis 2013; 19: 357-64.
5. Centres for Disease Control and Prevention. Measles cases and outbreaks. www.cdc.gov/ measles/cases-outbreaks.html (26.8.2015).

6. McNeil DGA. Multitude of vaccine benefits, yet controversy persists. The New York Times 28.3.2008.

7. Wikipedia. Maurice Hilleman. http://en.wikipedia. org/wiki/Maurice Hilleman (23.2.2015).

8. Obituary: Maurice Hilleman. The Economist 21.4.2005.

9. Babbott FL jr, Gordon JE. Modern measles. Am J Med Sci 1954; 228: 334-61.

10. Bloch $A B$, Orenstein WA Stetler $\mathrm{HC}$ et al. Health impact of measles vaccination in the United States. Pediatrics 1985; 76: 524-32.

11. Conniff RA. Forgotten pioneer of vaccines. The New York Times 6.5.2013

12. Ruud S. Regjeringen foreslår hepatitt B-vaksine for alle. Aftenposten 23.1.2015

13. Sela M, Hilleman MR. Therapeutic vaccines: realities of today and hopes for tomorrow. Proc Natl Acad Sci U S A 2004: 101 (suppl 2): 14559.

14. Deer $B$. How the case against the MMR vaccine was fixed. BMJ 2011; 342: c5347.

15. Wakefield AJ, Murch SH, Anthony A et al. Ileallymphoid-nodular hyperplasia, non-specific colitis, and pervasive developmental disorder in children. Lancet 1998; 351: 637-41.

16. Maugh TH, Hilleman MR. Scientist developed many vaccines that saved millions of lives. Los Angeles Times 13.4.2005.

Mottatt 27.2. 2015, første revisjon innsendt 13.6. 2015, godkjent 26.8. 2015. Redaktør: Kari Tveito. 